EDITORIAL

\title{
HISTÓRIA, DEMOCRACIA E INSTITUIÇÕES ${ }^{1}$
}

\author{
History, democracy and institutions
}

Historia, democracia e instituciones

\begin{abstract}
ANGELA MOREIRA DOMINGUES DA SILVA, MARCO AURÉLIO VANNUCCHI

PAULO FONTES

Fundação Getulio Vargas/FGV- Escola de Ciêndias Sodiais (CPDOC/FGV)

Rio deJaneiro - RJ, Brasil
\end{abstract}

EDITORES

\begin{abstract}
A $S$ atuais discussões a respeito do funcionamento das instituições nacionais e da qualidade da democracia brasileira motivaram a definição do presente tema da Revista Estudos Históricos, que se dedica a reflexões sobre História, democracia e instituições. A abrangência e importância do tema fez com que recebêssemos artigos refletindo sobre os mais variados temas, a partir de perspectivas bem distintas. Assim, neste número, contamos com textos sobre feminismo e participação das mulheres nas instituições, sobre distintas concepções de democracia na primeira metade do século XX, a partir do ponto de vista de juristas, sobre o processo de redemocratização brasileira na década de 1980 e as disputas em torno da noção de democracia, além de texto sobre o funcionamento do sistema de Justiça criminal brasileiro. Dessa forma, publicamos artigos que cobrem diferentes épocas da histórica repu-
\end{abstract}

http://dx.Doi.Org/10.1590/S2178-14942018000100001

Professores da Escola de Clências Sociais da Fundação Getulio Vargas (CPDOC/FGV) e Editores da Revista Estudos Históricos. E-mails: angelamoreirads@gmail.com; marco.vannucchi@fgv.br; paulo. fontes@fgv.br 
blicana brasileira.

0 artigo que abre este número da Revista trata de uma Uma história social do feminismo: diálogos de um campo político brasileiro (1917-1937), no qual Glaucia Cristina Candian Fraccaro contribui para reflexões sobre o feminismo - campo de disputas internacionais -, a partir da ótica do mundo do trabalho. Ao longo do artigo, Fraccaro enfatiza a luta das mulheres trabalhadoras por direitos e sua pouca representatividade nas instituições governamentais. 0 segundo artigo, A democracia em debate: juristas baianos e a resistência ao regime varguista (1930-1945), de Diego Rafael Ambrosini, busca analisar diferentes noções em circulação a respeito da ideia de democracia nas décadas de 1930 e 1940, especialmente a partir da perspectiva da produção intelectual de juristas que atuavam no Instituto dos Advogados da Bahia.

0 texto que segue, de Daniel Barbosa Andrade de Faria, analisa o incidente acontecido logo após a manifestação contra o Plano Cruzado II, conhecido como "badernaço", refletindo sobre as disputas em torno da noção de democracia, fundamentado na documentação do acervo da Secretaria de Segurança Pública do Distrito Federal. Pesquisando sobre a mesma época, Fernando Roque Fernandes analisa o debate parlamentar em torno da Constituição de 1988, no que concerne à pauta da cidadania indígena, quando democracia, cidadania e direitos humanos estavam na agenda de discussões para pensar a "nova democracia" brasileira. Por fim, o artigo de Flávia Cristina Soares e Ludmila Ribeiro que oferece um balanço bibliográfico sobre o funcionamento do sistema criminal brasileiro, registrando o descompasso entre os ideais da democracia e o pragmatismo do funcionamento das instituições de Justiça.

Fechando o dossiê, o número apresenta a entrevista realizada com o cientista político João Roberto Martins Filho, professor da Universidade Federal de São Carlos (UFSCar), sobre a história e a atuação política das Forças Armadas brasileiras. Além de narrar sua trajetória acadêmica, com início na Universidade Estadual de Campinas (Unicamp), Martins Filho registra o percurso de suas pesquisas sobre a instituição militar, tendo início na atuação política do Exército durante o período ditatorial brasileiro.

Este número é dedicado a Dulce Pandolfi, Luciana Heymann, Monica Kornis e Verena Alberti, acadêmicas fundamentais na história do CPDOC e da Revista Estudos Históricos.

\section{Referência bibliográfica}

${ }^{1}$ TILLY, Charles. Democracy. New York: Columbia University Press, 2007. 